The main causes of death in the world today is NON-COMmunicable diseases (NCDS). A research of the World Bank FOUND OUT THAT $82 \%$ OF DEATHS IN UKRAINE ARE CAUSED BY CHRONIC NCDs, 3.6\% OF WHICH COMPOSE DIABETES MELLITUS. AND SINCE THE COURSE OF TYPE 2 DIABETES MELLITUS (T2DM) IS USUALLY LONG, IT REQUIRES SPECIAL, COSTLY MEDICAL CARE FOR SIGNIFICANT PERIOD OF PATIENT'S LIFETIME.

\title{
MATERIAL'S RESEARCH
}

\section{Our research involved}

1762 people with T2DM

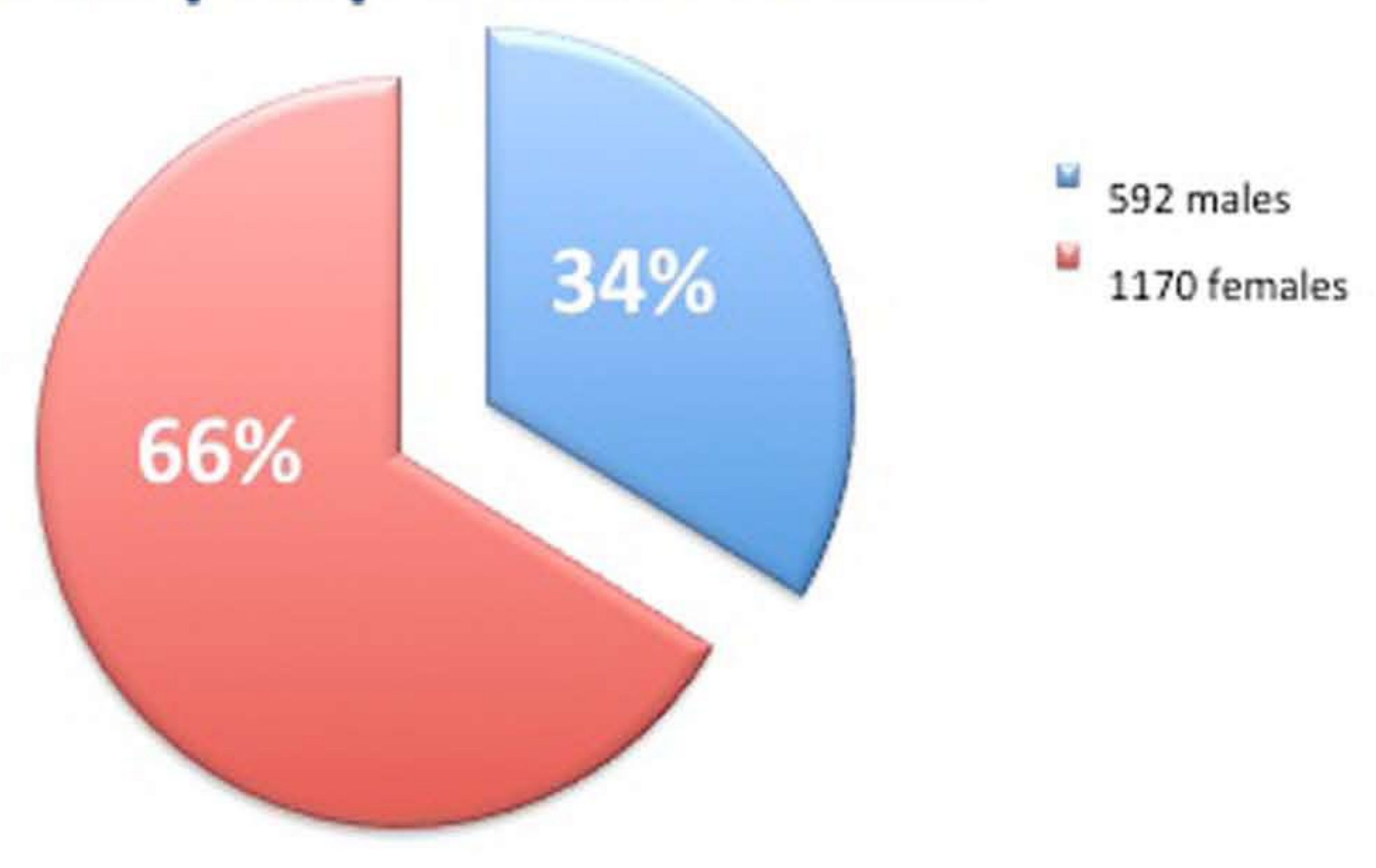

\begin{tabular}{|c|c|c|c|}
\hline \multicolumn{4}{|c|}{ Patients were divided, according to cholesterolemia } \\
\hline Cender Cholesterol & under $5.3 \mathrm{mmol} / \mathrm{L}$ & $5.3-6.5 \mathrm{mmol} / \mathrm{L}$ & over $6.5 \mathrm{mmol} / \mathrm{L}$ \\
\hline Males & $38 \%$ & $57 \%$ & $5 \%$ \\
\hline Females & $28 \%$ & $64 \%$ & $8 \%$ \\
\hline
\end{tabular}

\begin{tabular}{|c|c|c|c|}
\hline \multicolumn{4}{|c|}{ Regarding fasting glycemia, patients' groups were } \\
\hline$\overbrace{\text { Gender }}^{\text {Clysemia }}$ & under $6.2 \mathrm{mmol} / \mathrm{L}$ & $6.2-7.8 \mathrm{mmol} / \mathrm{L}$ & over $7.8 \mathrm{mmol} / \mathrm{L}$ \\
\hline Males (cholesterol level) & $5.70 \pm 0.01 \mathrm{mmol} / \mathrm{L}$ & $5.90 \pm 0.05 \mathrm{mmol} / \mathrm{L}$ & $5.99 \pm 0.04 \mathrm{mmol} / \mathrm{L}$ \\
\hline Females (cholesterol level) & $4.86 \pm 0.03 \mathrm{mmol} / \mathrm{L}$ & $6.50 \pm 0.03 \mathrm{mmol} / \mathrm{L}$ & $7.50 \pm 0.03 \mathrm{mmo} / \mathrm{L}$ \\
\hline
\end{tabular}

\begin{tabular}{|l|c|c|c|}
\hline \multicolumn{4}{|c|}{ Regarding BMI, patients' groups were } \\
\hline Cender & Normal weight & Overweight & Obesity \\
\hline Males (cholesterol level) & $5.81 \pm 0.06 \mathrm{mmol} / \mathrm{L}$ & $6.12 \pm 0.04 \mathrm{mmol} / \mathrm{L}$ & $6.10 \pm 0.05 \mathrm{mmo} / \mathrm{L}$ \\
\hline Females (cholesterol level) & $5.48 \pm 0.04 \mathrm{mmol} /$ & $5.56 \pm 0.02 \mathrm{mmo} / \mathrm{L}$ & $5.77 \pm 0.01 \mathrm{mmo} / \mathrm{L}$ \\
\hline
\end{tabular}

OUR RESEARCH INVOLVED 592 MALES AND 1170 feMALES WITH T2DM. We Determined BMI, GLYCEMIA, TOTAL CHOLESTEROL, HDL-C AND NON-HDL-C. DYSLIPIDEMIA IS ESTABLISHED WITH CHOLESTEROLEMIA OVER 5.20 MMOL/L AND WITH HDL-C UNDER $1.02 \mathrm{MMOL/L} \mathrm{IN} \mathrm{MALES} \mathrm{AND} \mathrm{UNDER}$ $1.29 \mathrm{MMOL} / \mathrm{L}$ IN FEMALES. IN OUR STUDY GROUP, CHOLESTEROL LEVEL IN MEN WAS $6.41 \pm 0.03 \mathrm{MMOL} / \mathrm{L}$, IN WOMEN $-6.23 \pm 0.01 \mathrm{MMOL} / \mathrm{L}(\mathrm{P}<0.05)$, WHILE HDL-C WAS RESPECTIVELY $1.89 \pm 0.88$ AND $1.88 \pm 0,07 \mathrm{MMOL} / \mathrm{L}(\mathrm{P}<0.05)$,

AND NON-HDL-C $-4.60 \pm 0.02$ AND $3.38 \pm 0.05 \mathrm{MMOL} / \mathrm{L}(\mathrm{P}<0.05)$.

PATIENTS WERE DIVIDED, ACCORDING TO CHOLESTEROLEMIA, INTO THE FOLLOWING GROUPS: UNDER 5.3, 5.3-6.5 AND OVER 6.5 MMOL/L.

IN RELATION TO THIS, MALES WERE THE FOLLOWING PERCENTAGES: $38 \%, 57 \%$, 5\%, AND FEMALES: $28 \%, 64 \%, 8 \%$.

REGARDING FASTING GLYCEMIA, PATIENTS' GROUPS WERE: UNDER $6.2,6.2-7.8$ AND OVER $7.8 \mathrm{MMOL} / \mathrm{L}$.

ACCORDINGLY, CHOLESTEROL LEVEL RELATED TO GLYCEMIC GROUPS IN MEN WAS 5.70 $\pm 0.01,5.90 \pm 0.05,5.99 \pm 0.04 \mathrm{MmOL} / \mathrm{L}(\mathrm{P}<0.001)$,

AND IN WOMEN: $4.86 \pm 0.03,6.50 \pm 0.03,7.50 \pm 0.03 \mathrm{MMOL} / \mathrm{L}(\mathrm{P}<0.001)$ RESPECTIVELY.

IN ACCORDANCE WITH BMI WE HAD THE FOLLOWING CLASSIFICATION: NORMAL WEIGHT, OVERWEIGHT, OBESITY.

AND MALE PATIENTS' CHOLESTEROL WAS RESPECTIVELY AS FOLlOWS: $5.81 \pm 0.06,6.12 \pm 0.04,6.10 \pm 0.05 \mathrm{mmOL} / \mathrm{L}$, WHILE FEMALE CHOLESTEROL:

$5.48 \pm 0.04,5.56 \pm 0.02,5.77 \pm 0.01 \mathrm{MMOL} / \mathrm{L}$.

\section{CONCLUSIONS:}

1. Atherogenic DYSLIPIDEMia in 70\% of PATIENTS With T2DM of BOth SEXES IS CAUSED by AN INCREASE IN BLOOD NON-HDL-C.

2. AtherogeniC DYSLIPIDEMIA CORRELATED WITH THE STATE OF COMPENSATION OF DIABETES AND BODY WEIGHT.

3. THERAPEUTIC CORRECTION OF DYSLIPIDEMIA IN PATIENTS WITH T2DM SHOULD BE NORMALIZATION OF BLOOD GLUCOSE AND BODY WEIGHT. 